Supplement of Geosci. Model Dev., 12, 2961-2982, 2019

https://doi.org/10.5194/gmd-12-2961-2019-supplement

(C) Author(s) 2019. This work is distributed under

the Creative Commons Attribution 4.0 License.

(c) (1)

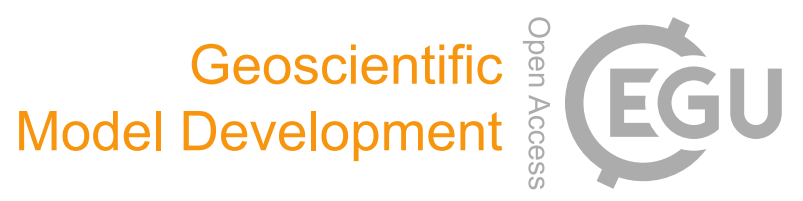

Supplement of

\title{
Modelling northern peatland area and carbon dynamics since the Holocene with the ORCHIDEE-PEAT land surface model (SVN r5488)
}

\section{Chunjing Qiu et al.}

Correspondence to: Chunjing Qiu (chunjing.qiu@1sce.ipsl.fr)

The copyright of individual parts of the supplement might differ from the CC BY 4.0 License. 


\section{Text S1.}

In the model, energy and water exchanges between land and the atmosphere, and the soil water budgets are simulated at a 30 min time step. The parameterization of soil water dynamics is from De Rosnay et al. (2000, 2002). Vertical diffusion of water in the 11 soil layers (with a total depth of $2.0 \mathrm{~m}$ ) of the soil column is solved by the FokkerPlanck equation, with hydraulic conductivity and diffusivity defined by the Mualem Van Genuchten model (Van Genuchten, 1980; Mualem, 1976). Processes related to the carbon cycle such as plant phenology, photosynthates allocation, litter and soil C decomposition are calculated at a daily time step (Krinner et al., 2005).

A new plant functional type (PFT) with shallow roots was introduced for peatland vegetation (Largeron et al., 2018). In grid-based simulations, peatland is a sub-grid hydrological soil unit (HSU) that receives surface runoff from surrounding nonpeatland HSU in the same grid cell, and has its bottom drainage flux reduced to zero, thus a high water content can be maintained in the peatland HSU where the standing water above the soil surface can reach up to $10 \mathrm{~cm}$ (Largeron et al., 2018). Qiu et al. (2018) improved the representation of peatlands in a revision referred to as ORCHIDEE-PEAT by implementing peat-specific hydraulics in the peatland HSU with high water content at saturation and high saturated hydraulic conductivity, while hydraulic parameters of non-peatland HSUs are determined by the dominant soil texture in the grid cell.

\section{Text S2.}

Following the CENTURY model (Parton et al., 1988), prescribed fractions of plant residues are added to the metabolic and structural litter pools. Litter from leaf and fruit of peat PFT is added to the top layer of litter pools, while belowground litter from root is added in depth discretized according to the exponential root profile of the peat PFT. To account for the fact that peatland vegetation develops shallow and extensive root systems to survive in the high stress conditions (a scarcity of oxygen and nutrients; spongy, acid soil) (Boutin and Keddy, 1993), the exponential root profile of the peat PFT is set an e-folding length of $30 \mathrm{~cm}$ (Largeron et al., 2018). The fraction of litter that 
31 is not respired into $\mathrm{CO}_{2}$ provides $\mathrm{C}$ input to the active, slow and passive soil $\mathrm{C}$ pools,

$55 \quad S R(\theta)=\left(\prod_{k=\theta_{0}}^{\theta} P R_{S R_{k}}\right) \cdot S R_{0}$,

where $\operatorname{SR}(\theta)$ is the soil respiration when the volumetric water content is $\theta, \mathrm{SR}_{0}$ is 
water content and is set to $0.01, \mathrm{k}$ is the soil volumetric water content at 0.02 moisture interval from the initial moisture $\left(\theta_{0}\right)$ to $\theta$.

Finally, relative respiration is calculated by dividing SR value in each 0.02 moisture interval by the maximum value obtained. The specific moisture modifier $\left(f_{M, l}\right)$ value was diagnosed at each time-step according to the simulated volumetric water content.

\section{Text S4.}

\section{The cost-efficient TOPMODEL}

In TOPMODEL, sub-grid-scale topography information and soil properties of a given watershed / grid cell are used to redistribute the grid-cell mean water table depth to delineate the extent of sub-grid area at maximum soil water content. This is achieved by relating the local water table of a sub-grid pixel with the mean water table of a watershed / grid cell, based on the spatial distribution of the compound topographic index (CTI)

The CTI indicates the likelihood of a pixel to be inundated, a pixel with a larger CTI having a greater potential to be inundated. With an assumed linear relationship between the local water table depth and the grid mean water table depth (Eq. 4), the minimum value of the topographic index $\left(\mathrm{CTI}^{*}\right)$ for a pixel to get flooded $\left(W T_{i}=0\right)$ can be calculated from Eq. 5.

$W T_{i}-\overline{W T}=-\frac{1}{m}\left(C T I_{i}-\overline{C T I}\right)$,

$C T I^{*}=\overline{C T I}+m \cdot \overline{W T}$,

where $W T_{i}$ (in meters) is the local water table depth at pixel $i, \overline{W T}$ is the grid mean water table depth, $\overline{C T I}$ is the mean CTI over the catchment, and $m\left(\mathrm{~m}^{-1}\right)$ is the saturated hydraulic conductivity decay factor with depth.

Accordingly, the flooded area of the grid cell consists of all its pixels with a local CTI greater than $\mathrm{CTI}^{*}$, and therefore the flooded area fraction $(f)$ can be calculated as the ratio of the total area of flooded pixels $\left(\mathrm{CTI}>\mathrm{CTI}^{*}\right)$ and the total area of the grid cell. To rule out pixels that have too low CTI values to be flooded (i.e. mountains, places with steep slopes) even though the grid cell mean water table is quite shallow, $C T I_{\min }$ is introduced to calculate the maximum possible flooded area fraction $\left(f_{\max }\right)$ of the grid 
cell. Thus $f_{\max }$ is the ratio of the total area of pixels with $\mathrm{CTI}>C T I_{\min }$ and the total area of the grid cell. Lastly, the flooded area fraction of the grid cell can be calculated as: $f_{f}=\min \left(f, f_{\max }\right)$.

An empirical relationship between $f$ and $\overline{W T}$ can be established for a given grid cell with a specific $\mathrm{m}$ value (Fig. S2a(1), and this relationship can be approximated by an asymmetric sigmoid function (Stocker et al., 2014):

$f_{\text {flood }}=\left(1+v \cdot e^{-k\left(\overline{W T_{x}}-q\right)}\right)^{-1 / v}$

Finally, the flooded area fraction of the grid cell $\left(f_{f}\right)$ can be replaced by $f_{s}=$ $\min \left(f_{\text {flood }}, f_{\text {max }}\right)$ (Fig. S2a(2)).

As demonstrated by Stocker et al. (2014), the choice of $m$ and $C T I_{\min }$ determines the parameter set $\left(v, k, q, f_{\max }\right)$. In contrast to their study, in which $m$ and $C T I_{\min }$ were considered as tunable but globally uniform parameters, we tested different combinations of $m(m=(5,6,7,8,9,10,11,12,13,14,15))$ and $C T I_{\min } \quad\left(C T I_{\min }=\right.$ $(4,5,6,7,8,9,10,11,12))$ at each grid cell and select the combination that matches with the CW-WTD wetlands map (Tootchi et al., 2019).

\section{The water table position}

The grid mean water table depth is calculated as the area-weighted mean water table of non-peatland soils (mineral soils) and peatland HSU:

$\overline{W T}=W T_{\text {peat }} \cdot f_{\text {peat }}+W T_{\text {mineral }} \cdot f_{\text {mineral }}$,

where $W T_{\text {peat }}$ is the water table depth of the peatland HSU in the grid, $f_{\text {peat }}$ the peatland area fraction in the grid, $W T_{\text {mineral }}$ is the water table of mineral soils in the grid, $f_{\text {mineral }}$ is the area fraction of mineral soils and equals to $1-f_{\text {peat }}$.

Water table depth of mineral soils is calculated as the saturation deficit (in meters) in the unfrozen part of the soil:

$W T_{\text {mineral }}=\sum_{i=1}^{k}\left(\frac{\theta_{i}}{\theta s_{\text {dominant }}} \cdot \Delta Z_{i}\right)-\sum_{i=1}^{k} \Delta Z_{i}$

where $\theta_{i}$ is the soil water content (liquid and ice) of mineral soils HSU at the layer $i$, 
$\theta s_{\text {dominant }}$ is the mineral soil water content at saturation and determined from the dominant soil texture in the grid, $\Delta Z_{i}(\mathrm{~m})$ is the thickness of the layer, $i$ runs from the top of the ground surface to the soil bottom, and $k$ the uppermost non-frozen soil layer. $k$ is employed here to take into account the existence of frozen soil layers. However, when the local non-frozen depth is low, water table level may be overestimated, causing an overestimation of flooded area. Therefore, we set an arbitrary condition for the calculation: the water table is calculated only when all soil layers in the top $18.6 \mathrm{~cm}$ (7 layers in total) are not frozen, otherwise, the water table is not calculated and the flooded area fraction is zero.

The calculation of peatland water table includes standing water $\left(W T_{a b}\right)$ of peatland (Qiu et al., 2018) and includes a rough representation of the effect of free-phase gas bubbles on water table level by subtracting a constant volumetric gas content $\left(g_{a}\right)$ from the saturated water content of peat $\left(\theta s_{\text {peat }}\right)$ :

$$
W T_{\text {peat }}=W T_{a b}+\sum_{i=1}^{k}\left(\frac{\theta_{i}}{\left(\theta s_{\text {peat }}-g_{a}\right)} \cdot \Delta Z_{i}\right)-\sum_{i=1}^{k} \Delta Z_{i}
$$

where $W T_{a b}$ is the height of the above-surface water reservoir, $\theta_{i}$ is soil water content of peat soil at the layer $i, \theta s_{\text {peat }}$ is the peat soil water content at saturation, all other parameters as defined in Eq. 8. The decomposition of peat produces several gases $\left(\mathrm{CH}_{4}, \mathrm{CO}_{2}, \mathrm{H}_{2} \mathrm{~S}\right)$ and when the production of these gases exceeds their equilibrium solubility in the soil solution, gas bubbles form (Kellner et al., 2005). As the bubbles accumulate and/or grow, some of them get bigger than pore diameters and get trapped in the peat matrix, which may further block the movement of water and gases, causing development of closed zones or layers - the "bubbles confining layers" (Glaser et al., 2004; Kellner et al., 2005; Romanowicz et al., 1995). Volumetric content of trapped gas in peat was estimated to range from 0 to 0.2 , whether a confining layer exists or not (Comas et al., 2011; Donald O. Rosenberry et al., 2006; Strack et al., 2005). As noted by several studies, entrapped gas bubbles affect both peatland hydrology and biogeochemistry (Baird and Waldron, 2003; Donald O. Rosenberry et al., 2006; Strack et al., 2005). Kellner et al. (2005) explicitly discussed how changes in gas bubble 
volume in the saturated zone of peat can alter the water table level: increase of bubble volume can push water out of pores in the saturated zone, resulting in a higher water table by pushing water upward; at the same time, the peat surface can be raised if the peat profile is compressible. The latter phenomena has been supported by observations and experiments in peatlands (Glaser et al., 2004; Strack et al., 2006), while the former is difficult to quantify in the field because the fluctuation of peat surface complicates the situation. The model cannot simulate dynamics of entrapped gases now, thus we subtract a constant gas fraction of $0.08\left(g_{a}\right)$ from $\theta s_{\text {peat }}$ to represent the maximum water content of peat. This value has also been used by Wania et al. (2009a) in calculation of the water table position in the LPJ-Why model. We acknowledge that our representation of gas bubbles in the equation (Eq. 9) remains open to question, considering that the accumulation of free-phase gases is temporally and spatially variable, and the response of the water table level to the existence of gas bubbles might be much more complicated than that represented by the equation.

\section{Text S5.}

According to the peatland distribution analysis by Gignac et al. (2000), $S W B=-6 \mathrm{~cm}$ is the minimum value at which the Sphagnum-dominated peatland can be found in western Canada, and this threshold works well in predicting the geographical distribution of Sphagnum-dominated peatland in North America. Alexandrov et al. (2016) proved that an excess of summer precipitation $\left(\mathrm{P}_{\mathrm{w}}>0.7 \mathrm{PET}+30 \mathrm{~mm} \mathrm{yr}^{-1}\right)$ is necessary to keep a positive water balance for peatland and thus is a key factor in determining peatland extent in West Siberia since the Last Glacial Maximum.

\section{Text S6.}

The initiation and development of northern peatlands followed the retreat of the icesheets (Gorham et al., 2007; MacDonald et al., 2006). To take into account the deglaciation of North America that triggered peatland expansion after ice sheet disappeared, in regional simulations, we define $N$ and $X$ according to the reconstructed glacial retreat in North America by Dyke (2004) at discrete epochs (Fig. S5). We 
assumed no peat inception before 12000 BP. At 12000 BP being the start of the Holocene (Fig. S5a), SubC was run for 12000 years $(X=2 \mathrm{ka}, N=6)$ for all un-glaciated areas (NA-120, Table S1). At 8900 BP (Fig. S5b), the Hudson Bay was still under the Laurentide Ice Sheet (Dyke, 2004). For areas that lost ice-sheet between 12000 BP and 8900 BP (NA-89, Table S1), the SubC was run for 5 times $(N=5)$, with the length of the last SubC being $0.9 \mathrm{ka}(X=0.9 \mathrm{ka})$. We used the latter date (8900 BP) to define values of $N$ and $X$ instead of using the middle date of the time interval, because newly deglaciated land was not immediately suitable for peat deposition and normally there was a lag between deglaciation and peatland initiation (Gorham et al., 2007; Harden et al., 1992; Payette, 1984). At 7400 BP (Fig. S5c), ice sheets nearly vanished and the Hudson Bay was ice-free while only the northern part of Quebec and the Baffin Island were still covered by ice. Thus we set $X=1.4$ ka and $N=4$ for all grid cells that lost ice-sheet between 8900 BP and 7400 BP (NA-74, Table S1). From 3200 BP (Fig. S5d), only a small last remnant of the Laurentide Ice Sheet only existed at Baffin Island, and we set $X=1.2 \mathrm{ka}$ and $N=2$ for the newly exposed lands (NA-32, Table S1).

The Eurasian ice sheet complex reached its maximum area and volume at about 21-20 ka BP, however, from then on, the ice sheets retreated fast (Hughes et al., 2016). By 12000 BP only Norway, Sweden (except the southern tip), Finland, Svalbard islands, Franz Josef Land and northern Novaya Zemlya were covered by ice (Fig. S6a). The Scandinavian Ice Sheet was restricted to south of the main watershed in southeastern Norway and east of the watershed in Sweden by 10000 BP (Fig. S6b) and was postulated to have disappeared by $9000 \mathrm{BP}$ or slightly earlier (Hughes et al., 2016). We divide Eurasia into two regions with different timings of deglaciation. First, for all unglaciated areas by 12000 BP (Fig. S6a) we run the SubC for 6 times $(N=6)$ with $X=2$ ka (EA120, Table S1). For glaciated areas at 12000 BP, we run the SubC for 5 times ( $N$ 5) with $X=0.9 \mathrm{ka}($ EA89, Table S1).

\section{Text S7.}

\section{Evaluation datasets for Northern peatlands area:}

1. World Inventory of Soil Emission potentials (WISE): 
The harmonized global soil profile dataset WISE comprises attribute data from 21000 soil profiles. Commonly used soil chemical and physical attributes are organic carbon, nitrogen $(\mathrm{N}), \mathrm{pH}$, cation exchange capacity of the soil, exchangeable nutrients, bulk density, weight percentages of sand, silt and clay-size materials etc. are considered in the dataset (Batjes, 2016). The database was compiled from the FAO Soil Database (FAO-SDB), various regional Soil and Terrain Databases (SOTER), the ISRIC-ISIS (Soil Information System), the Natural Resources Conservation Service (NRCS-USDA) and national contributions and soil surveys (Batjes, 2008, 2009). We queried the dataset for areas covered by histosols to approximate the distribution of peatlands and aggregated the data to the $1^{\circ}$ grid of the model to compare with ORHCIDEE-PEAT v2.0 output.

2. Global peatland distribution map (PEATMAP):

Xu et al. (2018) developed an improved global peatland map (PEATMAP) by reviewing a wide variety of global, regional and local scale peatland distribution information. For areas of overlap between two or more datasets, the best source data are the ones that 1) are most likely to be directly relevant to peatland extents, 2) have the finest spatial resolution and 3) have been most recently updated. This PEATMAP product amalgamated the most detailed and up-to-date data sources on peatland distribution at fine spatial resolutions. The original PEATMAP dataset in shapefile format, with polygons holding information of coverage and area of individual peatlands and peat complexes was interpolated into a $1^{\circ}$ grid.

3. International Mire Conservation Group Global Peatland Database (IMCG-GPD): The IMCG-GPD database (Joosten, 2010) contains an inventory of peatlands for the years 1990 and 2008 at regional and national levels. The database integrates peatland proxies (vegetation, land use etc.), observations and reports. Extent and status of peatlands, volume of the peat resource and estimates of $\mathrm{CO}_{2}$ emissions from different types of land use are included (Joosten, 2010).

We compare peat area estimates from these three datasets with the output of ORCHIDEE-PEAT v2.0 for the year 2008.

4. Peatland distribution map by Yu et al. (2010): 
235 The qualitative peatland map of Yu et al. (2010) consists of irregular grids delineating regions with the presence of peatlands $(>5 \%)$ based on geological inventories of countries/regions and histosols from the HWSD v1.1 (FAO et al., 2009). We projected this binary data onto $0.05^{\circ} \times 0.05^{\circ}$ latitude-longitude grids and aggregated it on $1^{\circ} \times 1^{\circ}$ grids to obtain a map of peatlands fractional cover. This fractional cover map indicates regions with significant peatland cover, not directly comparable to other quantitative benchmark data. We use this map to visualize regions with significant cover of peatland (Sect. 4.2).

\section{Soil organic carbon stocks:}

1. The WISE:

We queried the WISE database to extract bulk density and organic carbon content for the histosols component for each soil mapping unit, and calculated the SOC density for histosols after excluding the coarse soil fraction. Note that the WISE only has C inventories to a depth of $2 \mathrm{~m}$, while the model has a depth up to $48 \mathrm{~m}$.

2. The IMCG-GPD:

We compared the carbon stocks estimate by IMCG-GPD in 2008 with the model output.

(1)


267 Table S1. Information for the peat cores included in the site simulation, and for the 268 regions included in the regional simulation. Peat cores are from the HPPB database 269 (Loisel et al., 2014). $X$ : simulation years in the last SubC run, $Y$ : number of years in the 270 transient simulation, $N$ : number of acceleration procedures. For site simulation, $Y=$ the 271 year of coring $-1860, X=$ the age of the core $-2000 \times(N-1)-30 \times N-100-Y$; for 272 regional simulation, $Y=150, X$ is defined according to the pattern and timing of 273 deglaciation. NA-120, NA-89, NA-74, NA-32, EA-120 and EA-89 are derived from 274 reconstructed glacial retreat of North America and Eurasia, refer to Sect. 3.2, Fig. S5 275 and Fig.S6. Red lines are 15 sites for which peat age, depth, bulk density and fraction 276 of $\mathrm{C}$ are available so that observed $\mathrm{C}$ vertical profile can be built.

\begin{tabular}{|c|c|c|c|c|c|c|c|c|}
\hline Site-level simulation & & & & & & & & \\
\hline Core name & Latitude & Longitude & Age & $\begin{array}{l}\text { Coring } \\
\text { year }\end{array}$ & Depth & $X$ & $N$ & $Y$ \\
\hline Hongyuan HYLK1 & 32.77 & 102.52 & 10827 & 2006 & 617.5 & 2431 & 5 & 146 \\
\hline Zoige & 33.45 & 102.63 & 9996 & 2008 & 640.5 & 3628 & 4 & 148 \\
\hline Sidney bog & 44.39 & -69.79 & 10789 & 2010 & 724.0 & 2389 & 5 & 150 \\
\hline Covey Hill & 45 & -73.49 & 12720 & - & 309.0 & 2290 & 6 & 150 \\
\hline Petite Bog & 45.14 & -63.94 & 13474 & 2010 & 861.0 & 3044 & 6 & 150 \\
\hline Altay & 48.12 & 88.35 & 11308 & 2010 & 729.5 & 2908 & 5 & 150 \\
\hline Lebel & 49.1 & -68.25 & 5831 & 2009 & 574.5 & 3522 & 2 & 149 \\
\hline Plaine & 50.27 & -63.54 & 7451 & 2009 & 356.5 & 3112 & 3 & 149 \\
\hline JBL8 & 50.47 & -89.93 & 4481 & 2008 & 189.0 & 2173 & 2 & 148 \\
\hline JBL1 & 51.07 & -89.8 & 6051 & 2008 & 285.0 & 1713 & 3 & 148 \\
\hline Burnt Village & 51.13 & -55.93 & 8526 & 2010 & 546.0 & 2156 & 4 & 150 \\
\hline $\mathrm{KJ} 2-3$ & 51.59 & -81.76 & 4677 & 2009 & 245.5 & 2368 & 2 & 149 \\
\hline Mosaik & 51.98 & -75.4 & 7072 & 2006 & 296.5 & 2736 & 3 & 146 \\
\hline JBL2 & 52.02 & -90.13 & 6742 & 2008 & 421.0 & 2404 & 3 & 148 \\
\hline Sterne & 52.05 & -75.17 & 7134 & 2006 & 286.0 & 2798 & 3 & 146 \\
\hline Goldeye Lake & 52.46 & -16.19 & 9207 & 1999 & 324.5 & 2848 & 4 & 139 \\
\hline Lac Le Caron & 52.58 & -75.83 & 7510 & 2006 & 481.5 & 3174 & 3 & 146 \\
\hline VC04-06 & 52.71 & 84.18 & 6599 & 2009 & 304.0 & 2260 & 3 & 149 \\
\hline JBL3 & 52.87 & -89.93 & 7708 & 2008 & 244.5 & 3370 & 3 & 148 \\
\hline La Grande 3 & 53.57 & -76.13 & 6816 & 2004 & 374.5 & 2482 & 3 & 144 \\
\hline Sundance Fen 03-3 & 53.58 & -116.75 & 10914 & 2003 & 438.5 & 2521 & 5 & 143 \\
\hline Upper Pinto Fen & 53.58 & -118.02 & 7699 & 1999 & 385.0 & 3370 & 3 & 139 \\
\hline La Grande 2 & 53.65 & -77.73 & 6543 & 2004 & 319.5 & 2209 & 3 & 144 \\
\hline KAM12-C4 & 54.01 & 156.08 & 12708 & 2012 & 395.5 & 2276 & 6 & 152 \\
\hline Ours 1 & 54.05 & -72.45 & 5491 & 2005 & 109.5 & 3186 & 2 & 145 \\
\hline JBL7 & 54.4 & -89.52 & 7607 & 2008 & 330.0 & 3269 & 3 & 148 \\
\hline
\end{tabular}




\begin{tabular}{|c|c|c|c|c|c|c|c|c|}
\hline HL-02 & 54.61 & -84.6 & 4494 & 2011 & 229.5 & 2183 & 2 & 151 \\
\hline Slave Lake bog & 55.06 & -114.13 & 10285 & 1989 & 384.0 & 1906 & 5 & 129 \\
\hline KUJU-PD2 & 55.23 & -77.7 & 5084 & 2008 & 243.5 & 2776 & 2 & 148 \\
\hline JBL4 & 55.27 & -88.93 & 6051 & 2008 & 175.5 & 1713 & 3 & 148 \\
\hline Joey Lake 7 & 55.46 & -98.16 & 8256 & 2001 & 228.5 & 1895 & 4 & 141 \\
\hline Utikuma & 55.84 & -115.09 & 5079 & 2004 & 370.5 & 2775 & 2 & 144 \\
\hline Patuanak & 55.85 & -107.68 & 9017 & 2001 & 310.0 & 2656 & 4 & 141 \\
\hline Mariana Lake 03-1 & 55.9 & -112.09 & 7222 & 2003 & 471.5 & 2889 & 3 & 143 \\
\hline Mariana Lake 03-3 & 56.02 & -111.93 & 5872 & 2003 & 384.5 & 3569 & 2 & 143 \\
\hline 86-Kvartal (Zh0) & 56.33 & 84.58 & 8651 & - & 725.0 & 2281 & 4 & 150 \\
\hline Vasyugan (V21) & 56.83 & 78.42 & 9709 & - & 1095.0 & 3349 & 4 & 150 \\
\hline Usinsk Mire 1 & 57.42 & 65.67 & 11634 & 1996 & 395.0 & 3248 & 5 & 136 \\
\hline Glen Carron & 57.53 & -5.15 & 10334 & 1994 & 360.0 & 1950 & 5 & 134 \\
\hline SIB06 & 58.44 & 83.43 & 8680 & 2001 & 365.5 & 2319 & 4 & 141 \\
\hline Lake 785 & 59.11 & -97.4 & 6833 & 2012 & 157.5 & 2491 & 3 & 152 \\
\hline Lake 396 & 59.58 & -98.57 & 6077 & 2012 & 95.5 & 1735 & 3 & 152 \\
\hline Selwyn Lake 1 & 59.88 & -104.2 & 6452 & 2002 & 195.5 & 2120 & 3 & 142 \\
\hline Horse Trail & 60.42 & -150.9 & 12695 & 2005 & 413.0 & 2270 & 6 & 145 \\
\hline Kenai Gasfield 07-2 & 60.45 & -151.25 & 11448 & 2007 & 283.1 & 3051 & 5 & 147 \\
\hline Bear & 60.53 & -145.45 & 10357 & 2010 & 351.5 & 1957 & 5 & 150 \\
\hline Swanson & 60.79 & -150.83 & 14065 & 2004 & 245.0 & 1611 & 7 & 144 \\
\hline V34 & 61.47 & 79.46 & 8824 & 1999 & 277.5 & 2465 & 4 & 139 \\
\hline Martin River & 61.8 & -121.4 & 7552 & - & 243.9 & 3212 & 3 & 150 \\
\hline Siikaneva & 61.84 & 24.17 & 9622 & 2012 & 551.0 & 3250 & 4 & 152 \\
\hline Petersville (09-MC) & 62.42 & -150.68 & 13881 & 2008 & 256.5 & 3453 & 6 & 148 \\
\hline D127 & 64.31 & 70.29 & 10034 & 1999 & 199.5 & 1645 & 5 & 139 \\
\hline Nuikluk 10-2 & 64.83 & -163.45 & 9143 & 2010 & 188.5 & 2773 & 4 & 150 \\
\hline NW-BG-2 & 65.21 & -127.01 & 10932 & 2008 & 128.0 & 2534 & 5 & 148 \\
\hline Saarisuo & 65.65 & 27.32 & 9138 & 1990 & 510.0 & 2788 & 4 & 130 \\
\hline E-110 & 66.47 & 76.99 & 9496 & 2000 & 192.5 & 3136 & 4 & 140 \\
\hline Rogovaya River 3 & 67.25 & 62.07 & 10088 & 1995 & 167.5 & 1703 & 5 & 135 \\
\hline Lompolojänkkä & 68 & 24.22 & 9969 & 2010 & 215.0 & 3599 & 4 & 150 \\
\hline IN-BG-1 & 68.32 & -133.42 & 9121 & 2007 & 375.0 & 2754 & 4 & 147 \\
\hline Stordalen & 68.35 & 19.05 & 4717 & 2003 & 100.0 & 2414 & 2 & 143 \\
\hline \multicolumn{9}{|c|}{ Regional simulation } \\
\hline & \multicolumn{2}{|c|}{ NA-120, EA-120 } & \multicolumn{3}{|l|}{12000} & 2000 & 6 & 150 \\
\hline & \multicolumn{2}{|c|}{ NA-89, EA-89 } & 8900 & & & 900 & 5 & 150 \\
\hline & \multicolumn{2}{|c|}{ NA-74 } & 7400 & & & 1400 & 4 & 150 \\
\hline & \multicolumn{2}{|c|}{ NA-32 } & 3200 & & & 1200 & 2 & 150 \\
\hline
\end{tabular}



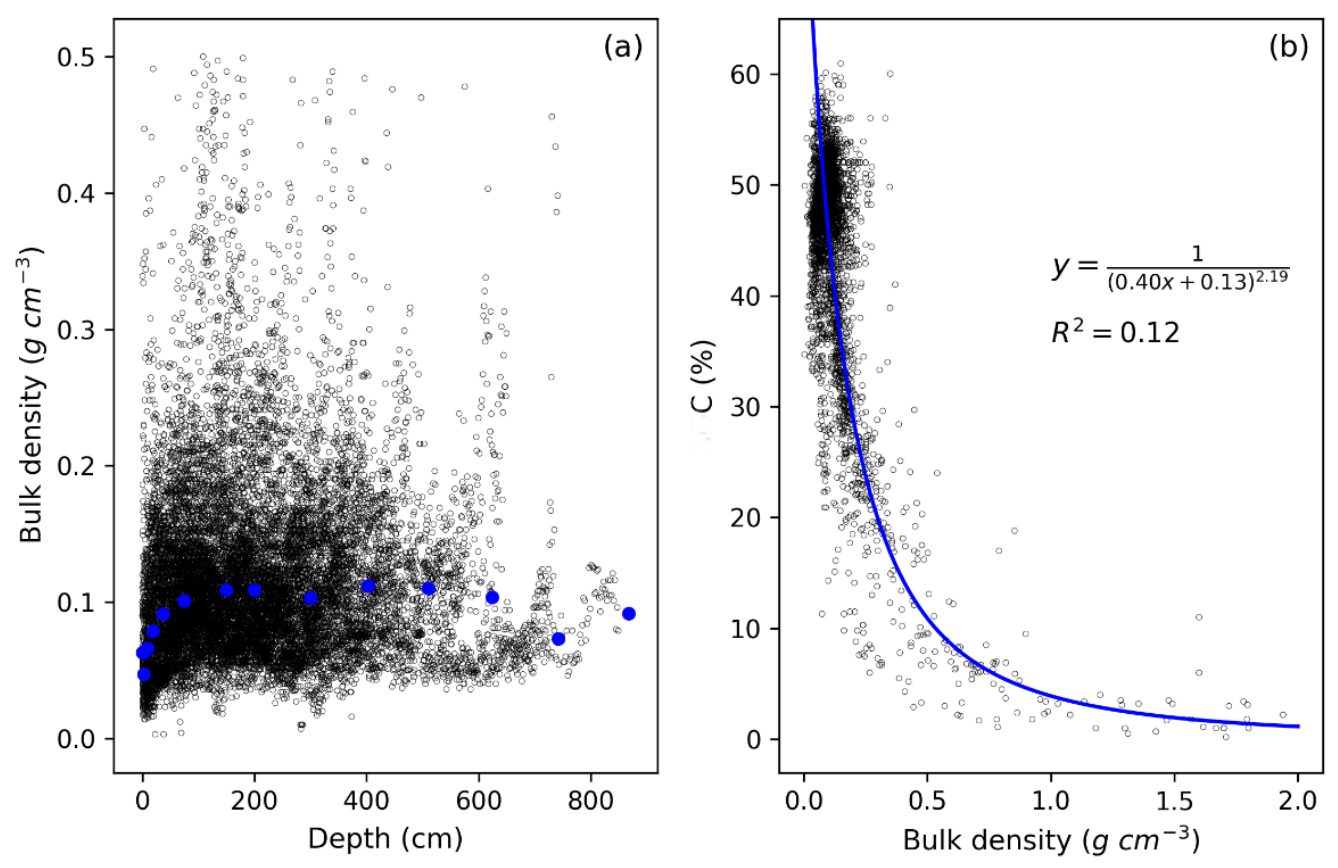

Fig. S1. (a) Measured bulk densities from 102 peat cores (black dots) and the median 286 value at each depth bin (blue dots), (b) the relationship between soil carbon fraction (\% weight) and bulk density. 


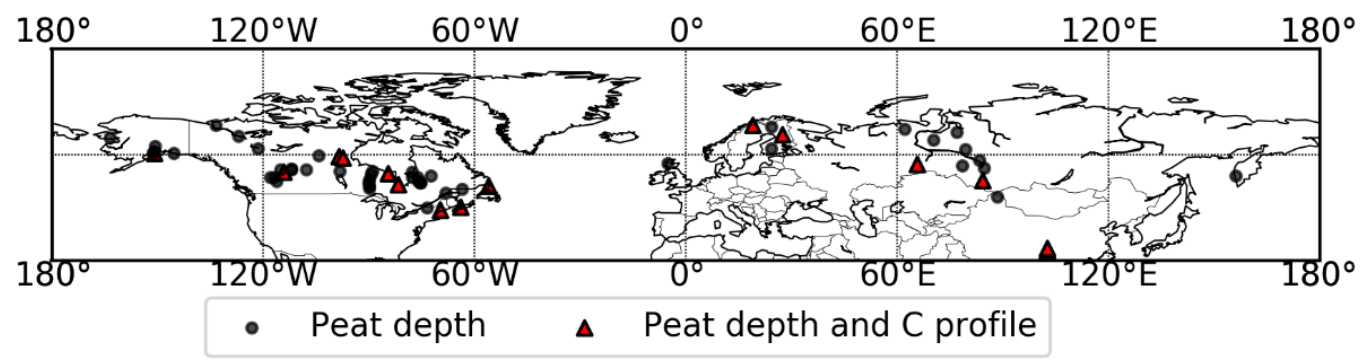

Fig. S2. Locations of the peatland cores used in site-level simulations. Marker: black circle - cores for which only peat age and depth were available, red triangle - cores for which peat age, depth, bulk density and carbon fraction were available so that $\mathrm{C}$ density vertical profile can be built.

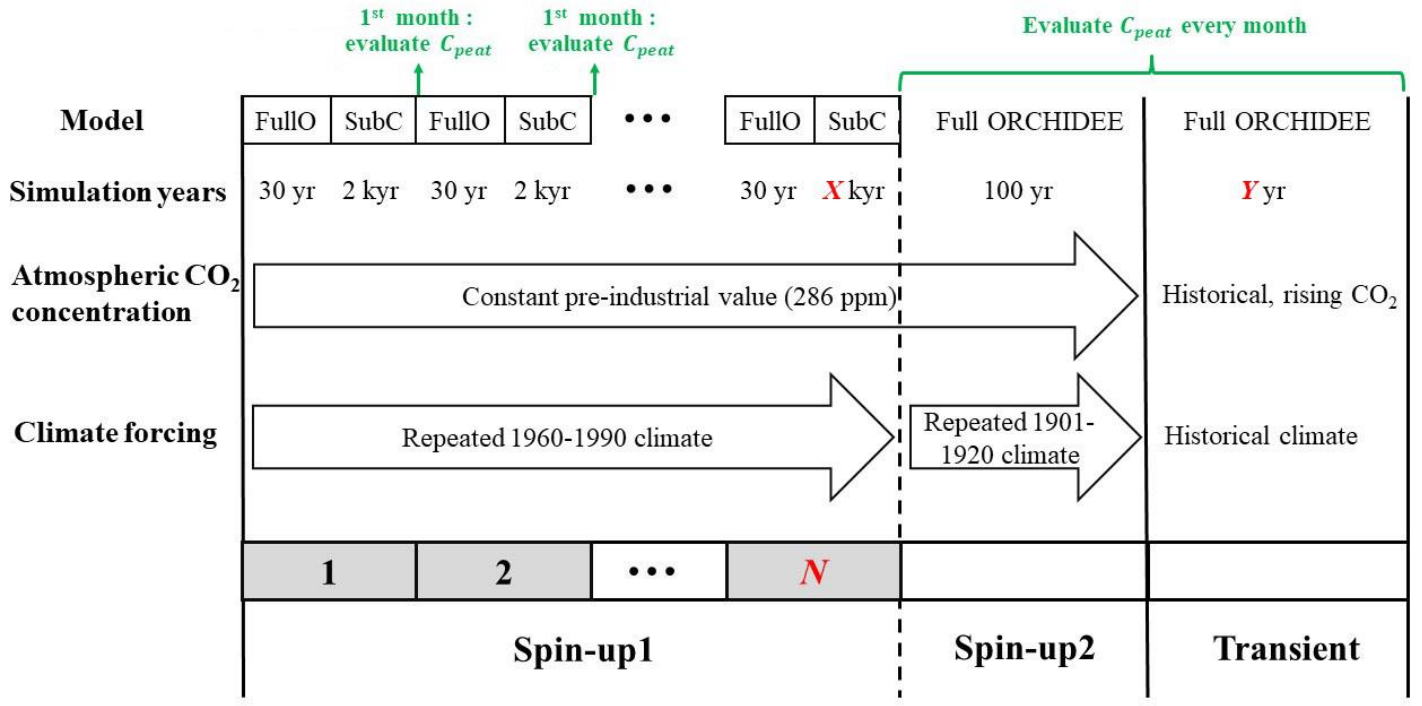

Fig. S3. Simulation Protocol. FullO: the full ORCHIDEE-PEAT v2.0 model, SubC: the soil carbon sub-model. Refer to Sect. 3.1 for detailed description of simulations. 

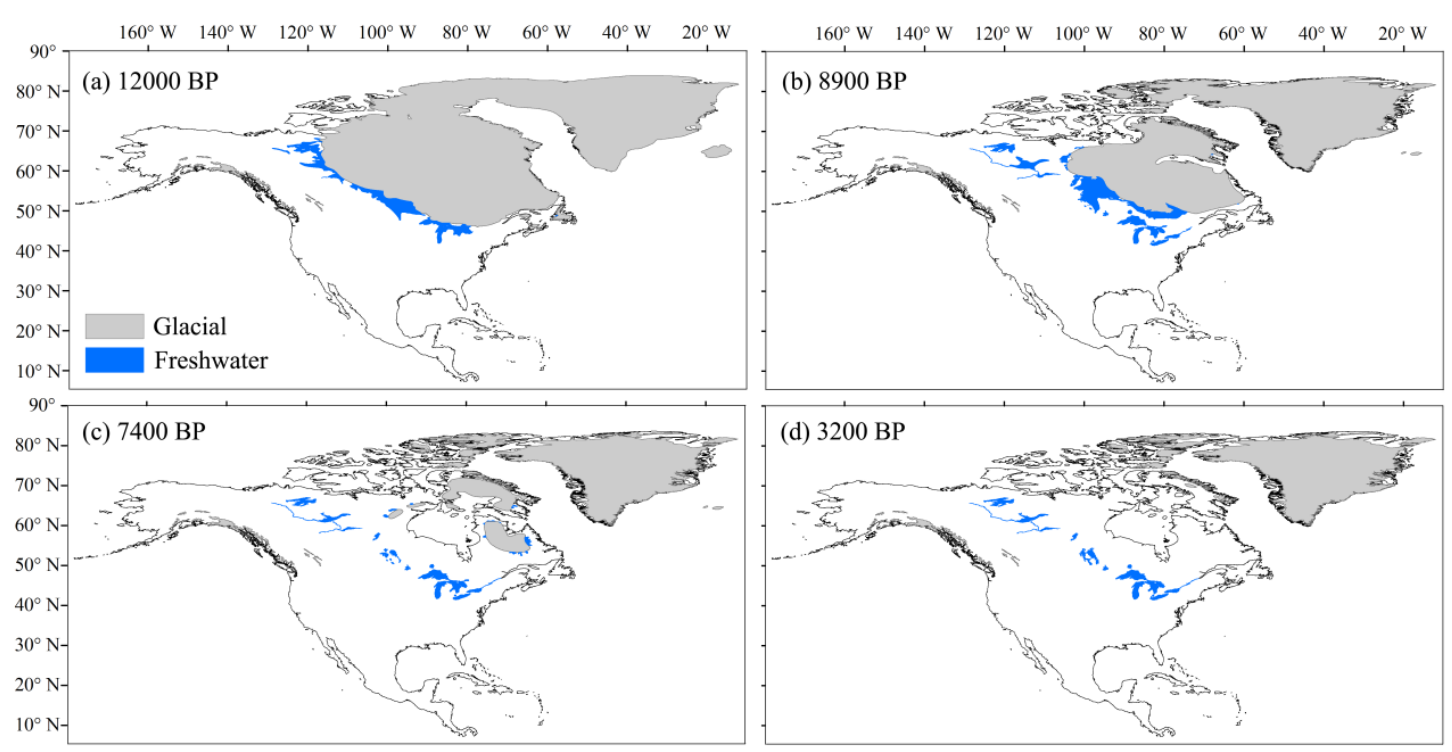

Fig. S4. Reconstructed maps of glaciated North America by (a) 12000 BP, (b) 8900 BP, (c) 7400 BP, (d) 3200 BP, redrawn from Dyke (2004).

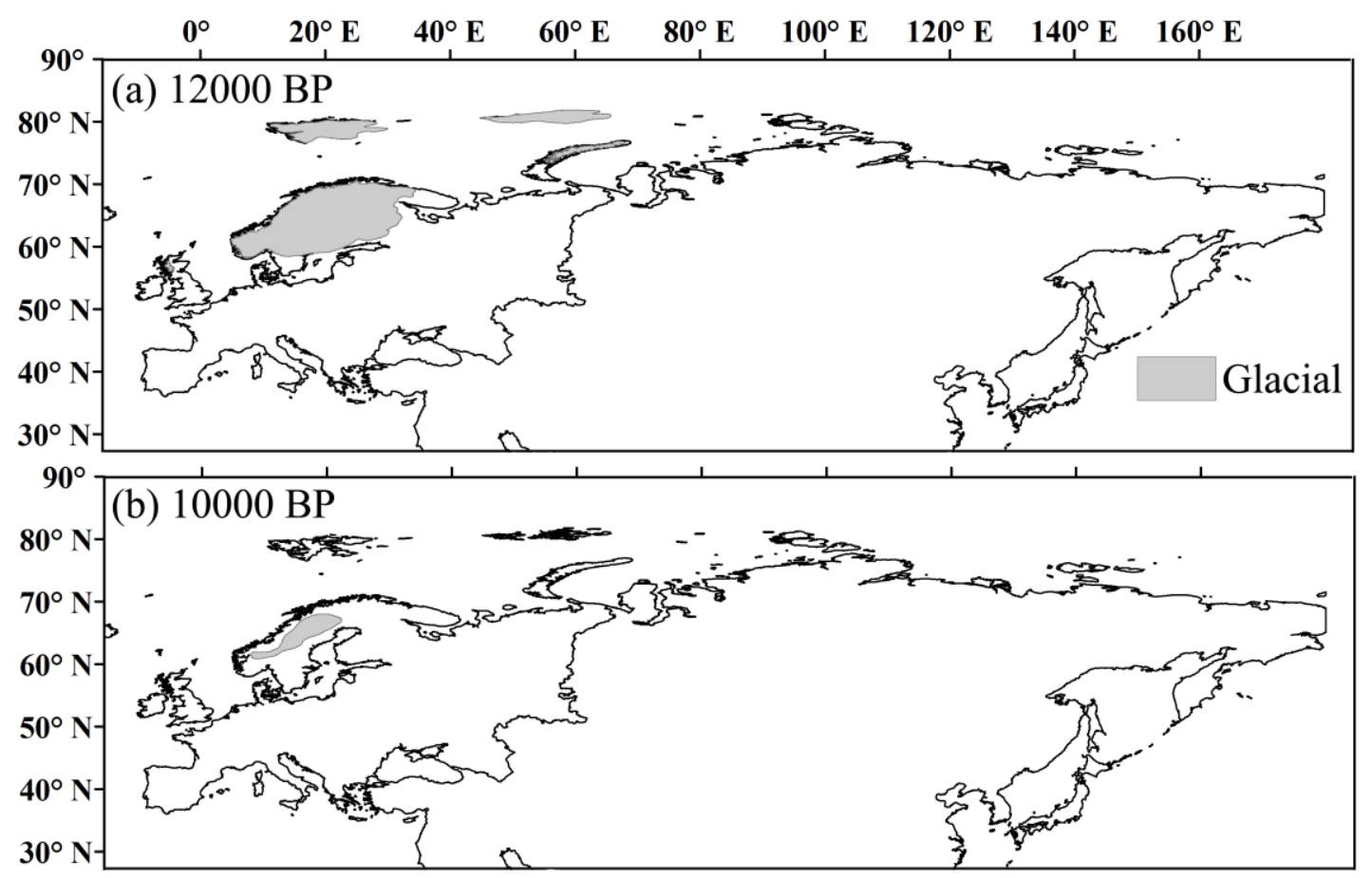

Fig. S5. Reconstructed glacial extent of Eurasia ( $>30^{\circ}$ N) by (a) $12000 \mathrm{BP}$, (b) 10000 BP; redrawn from Hughes et al. (2016). 


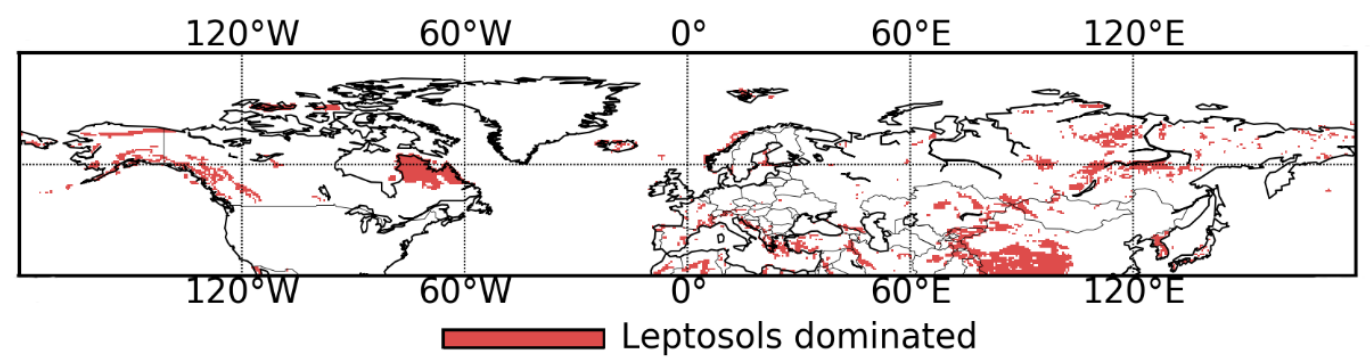

Fig. S6. Leptosols dominated grid cells, from the harmonized global soil profile dataset (WISE). 

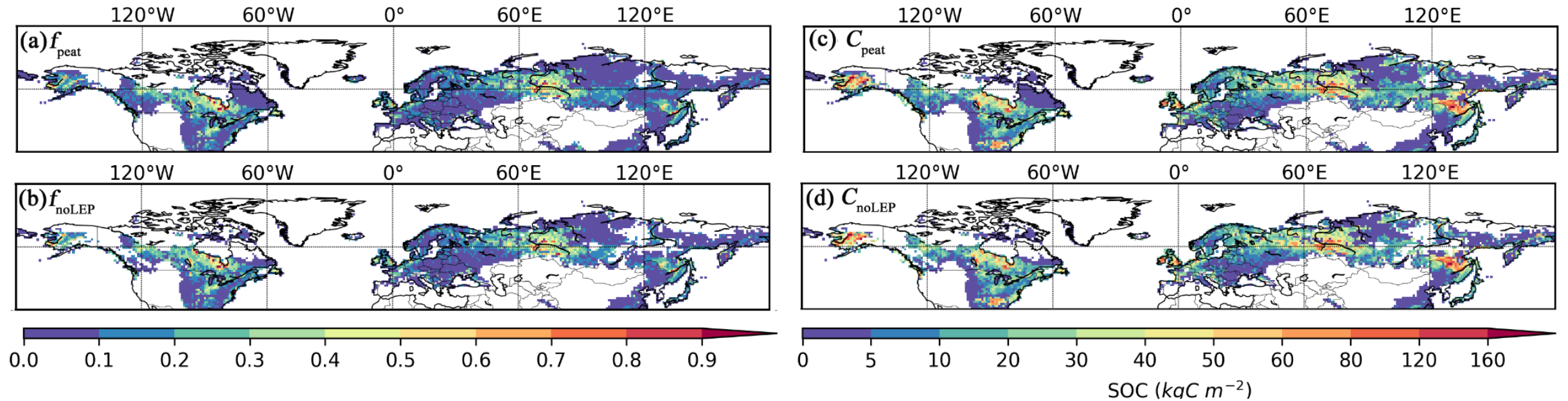

Fig. S7. (a) Simulated peatland area fraction $\left(f_{\text {peat }}\right)$, with pattern and timing of deglaciation has been considered; (b) same as (a), but areas dominated by Leptosols have been masked; (c) simulated peatland soil carbon density $\left(C_{\text {peat }}\right)$, with pattern and timing of deglaciation has been considered; (d) same as (c), but areas dominated by Leptosols have been masked. 


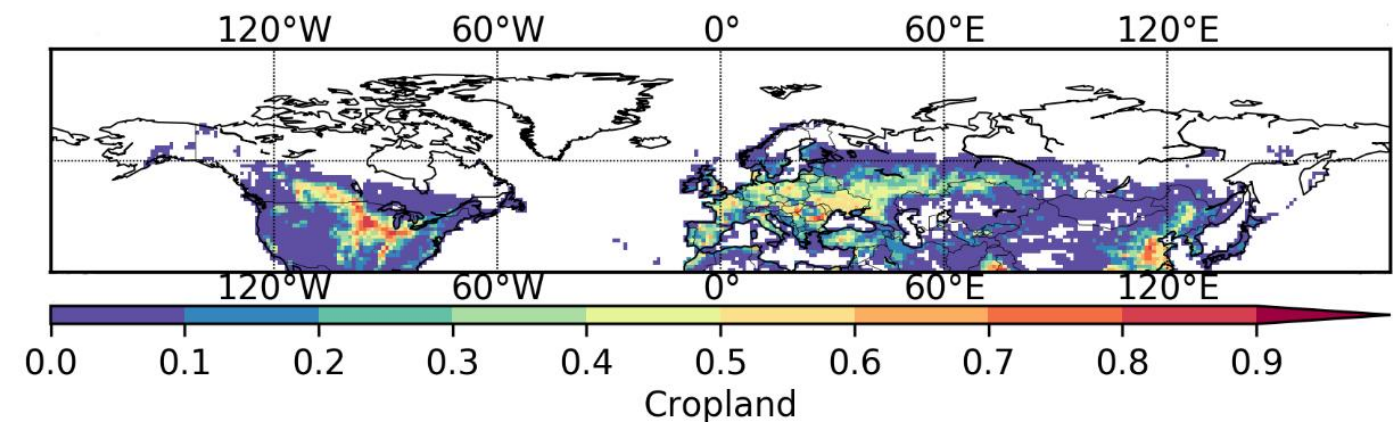

Fig. S8. Maximum monthly growing area fraction of 26 crops, from the global data set of monthly irrigated and rainfed crop areas around the year 2000 (MIRCA2000). 

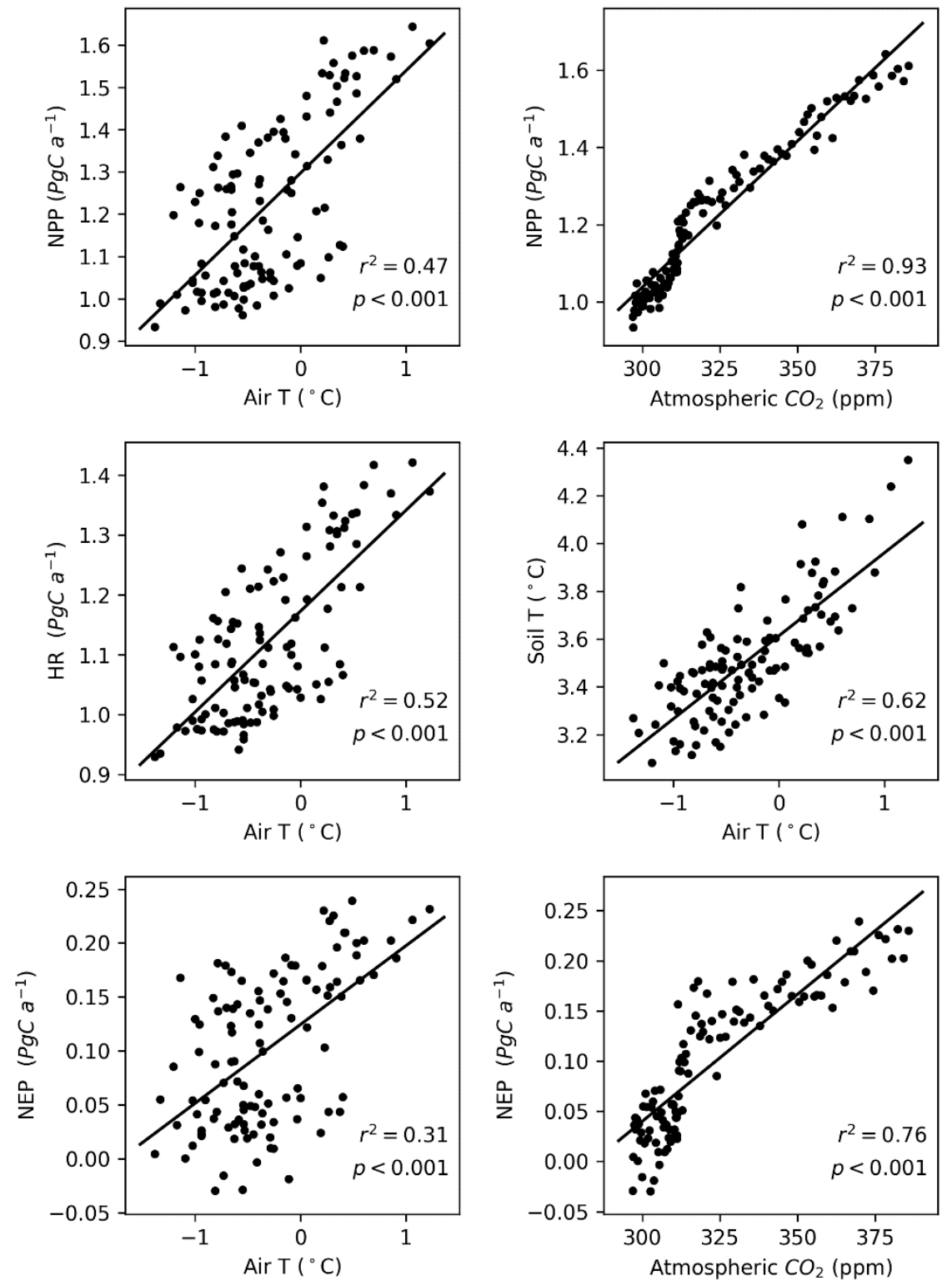

Fig. S9. Regression analysis for the relationship between (top-left) simulated net primary production (NPP) of northern peatlands and mean air temperature (T) of grid cells that have peatland, (top-right) NPP and atmospheric $\mathrm{CO}_{2}$ concentration, (middleleft) heterotrophic respiration (HR) of northern peatlands and air T, (middle-right) simulated soil temperature at $25 \mathrm{~cm}$ and air T, (bottom-left) net ecosystem production (NEP) and air T, (bottom-right) NEP and atmospheric $\mathrm{CO}_{2}$ concentration. 

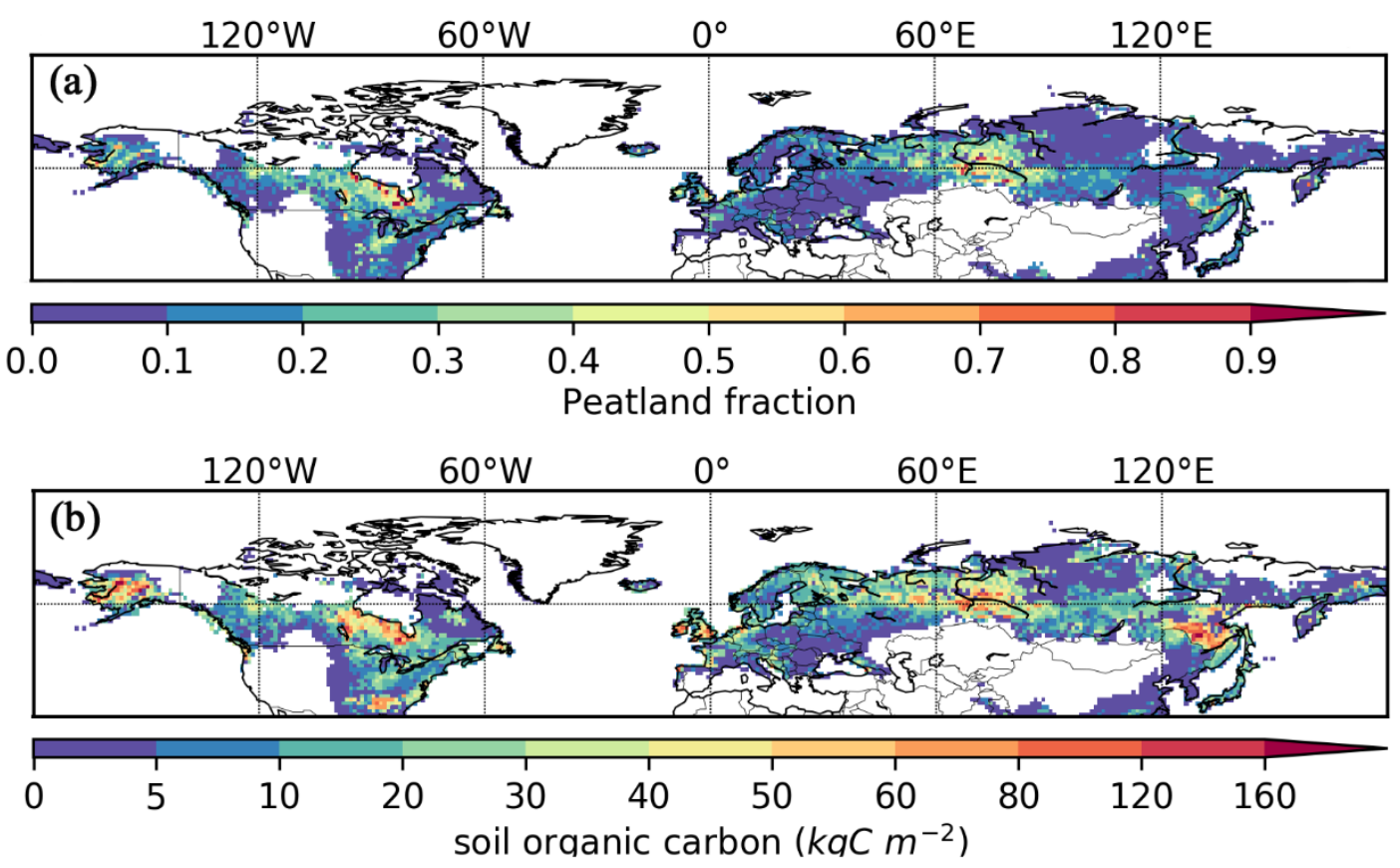

Fig. S10. Simulated peatland area fraction (a) and peat soil carbon density (b) when pattern and timing of ice sheets retreat are not considered (the model was run for 12,000 years), Leptosols and agricultural peatlands are included. 


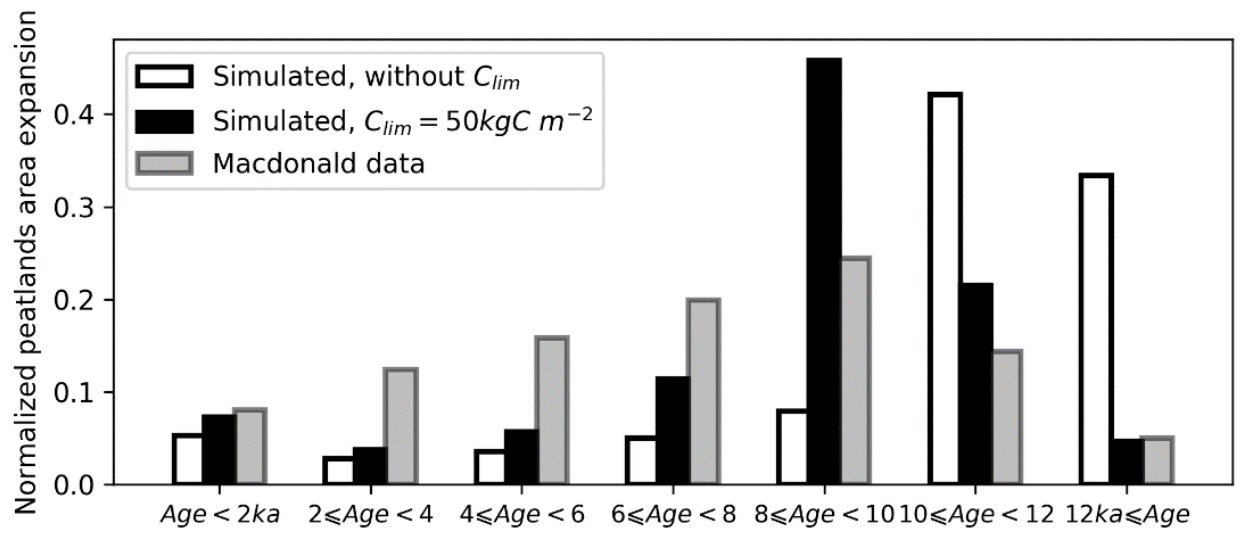

Fig. S11. (Grey bars) Percentage of observed peatland initiation in 2000-year bins. Peat basal dates of 1516 cores are from MacDonald et al. (2006), peat basal age frequency of each 2000-year bin is divided by the total peat basal age frequency. (Black bars) Percentage of simulated peatlands area developed in each 2000-year bin. The peatlands area developed in each bin is divided by the simulated modern (the year 2009) peatlands area. (White bars) Percentage of simulated peatlands area developed in each 2000-year bin when carbon density criterion $\left(C_{\text {lim }}\right)$ for peatland expansion has been removed. Note that deglaciation of ice-sheets is not considered in both simulations (the model was run for 12,000 years). 

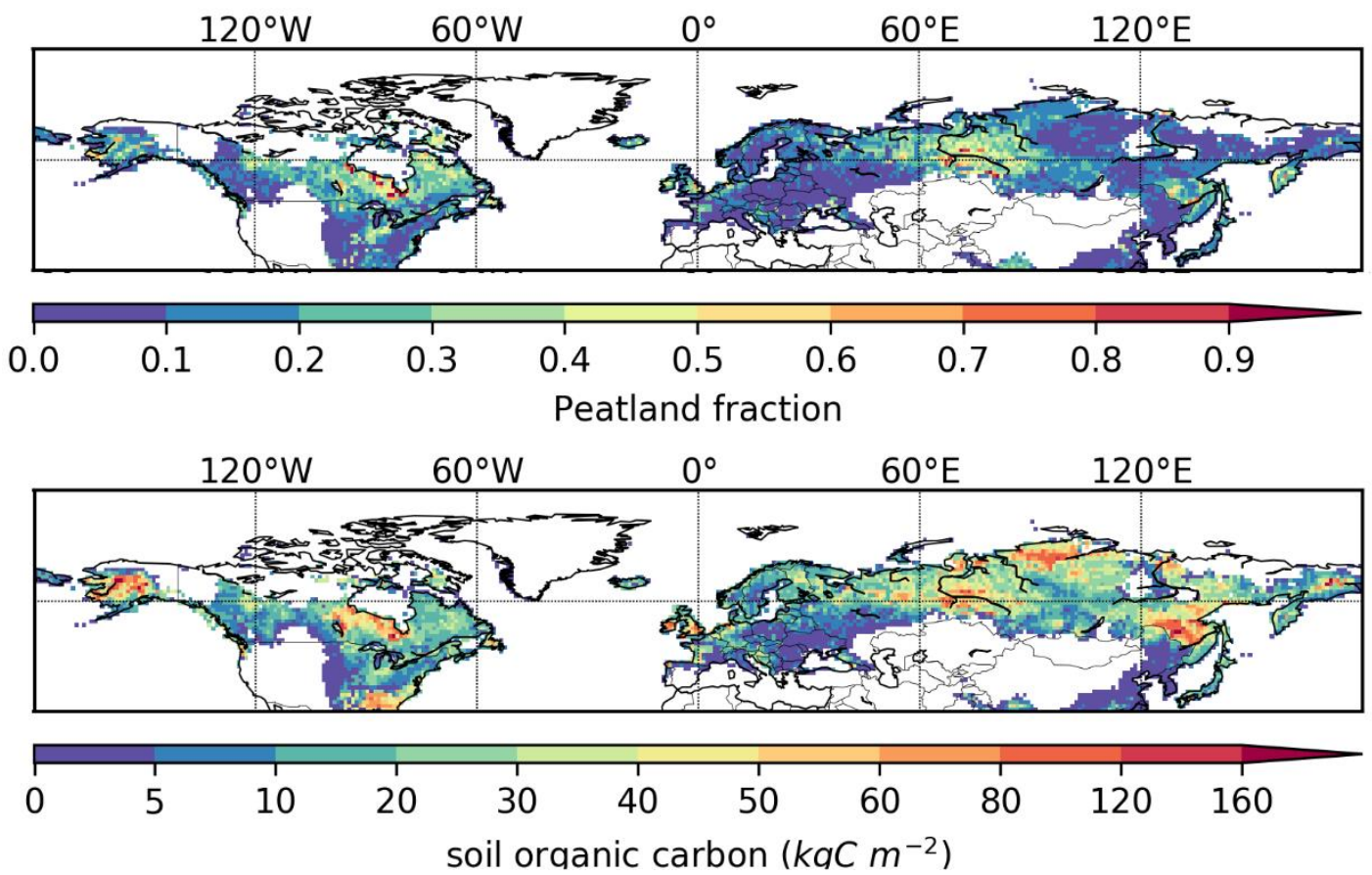

Fig. S12. Same to Fig. S10, but carbon density criteria $\left(C_{\text {lim }}\right)$ for peatland expansion has been removed. 

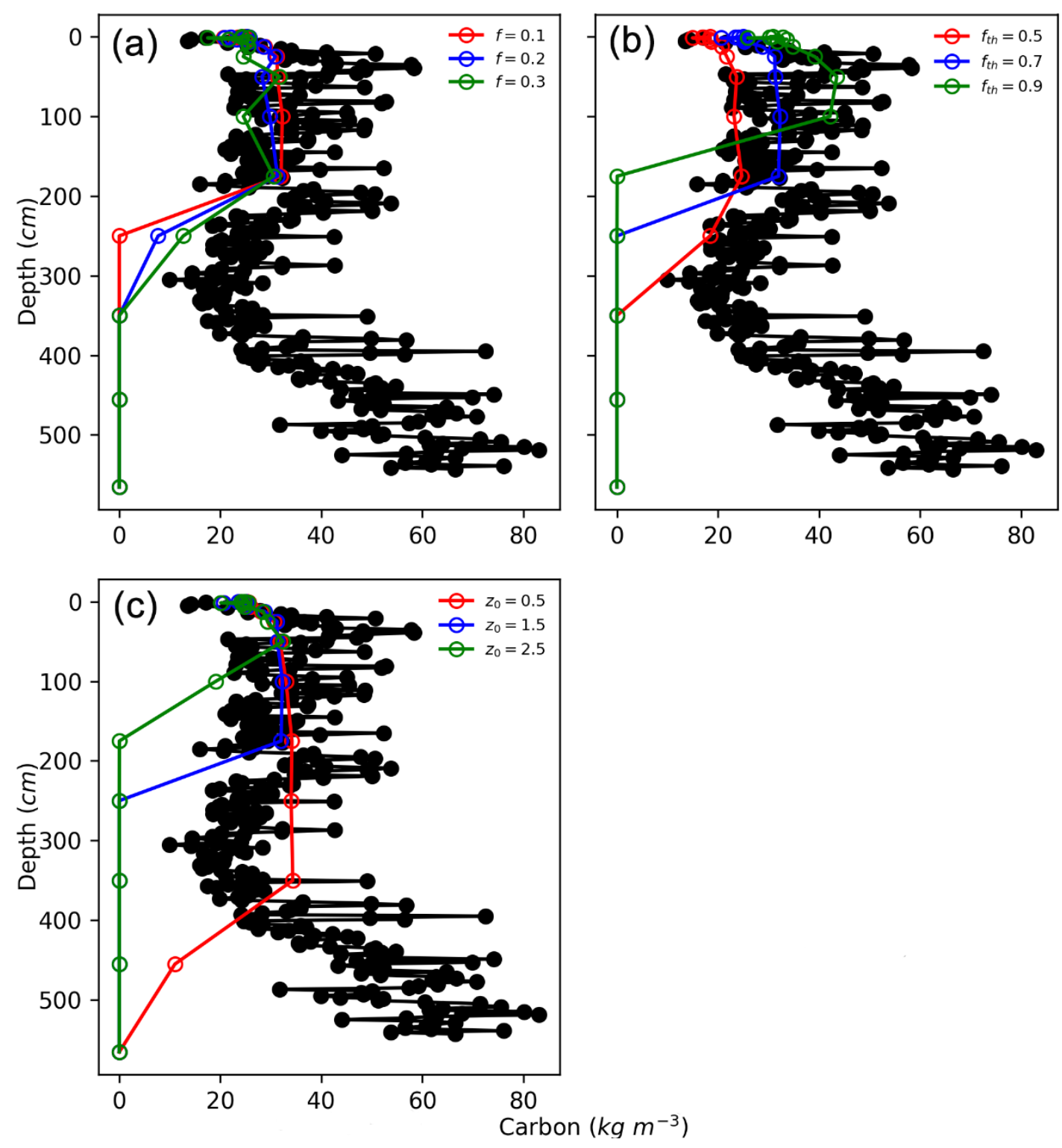

Fig. S13. Observed (black) and simulated (colored) vertical profiles of soil C of Burnt Village. (a) changing the prescribed fraction of $\mathrm{C}$ to be transferred $(f),(\mathrm{b})$ changing the prescribed threshold to allow $\mathrm{C}$ transfer between soil layers $\left(f_{t h}\right),(\mathrm{c})$ changing the efolding depth of intrinsic decomposition rate $\left(z_{0}\right.$, in $\left.\mathrm{m}\right)$. 

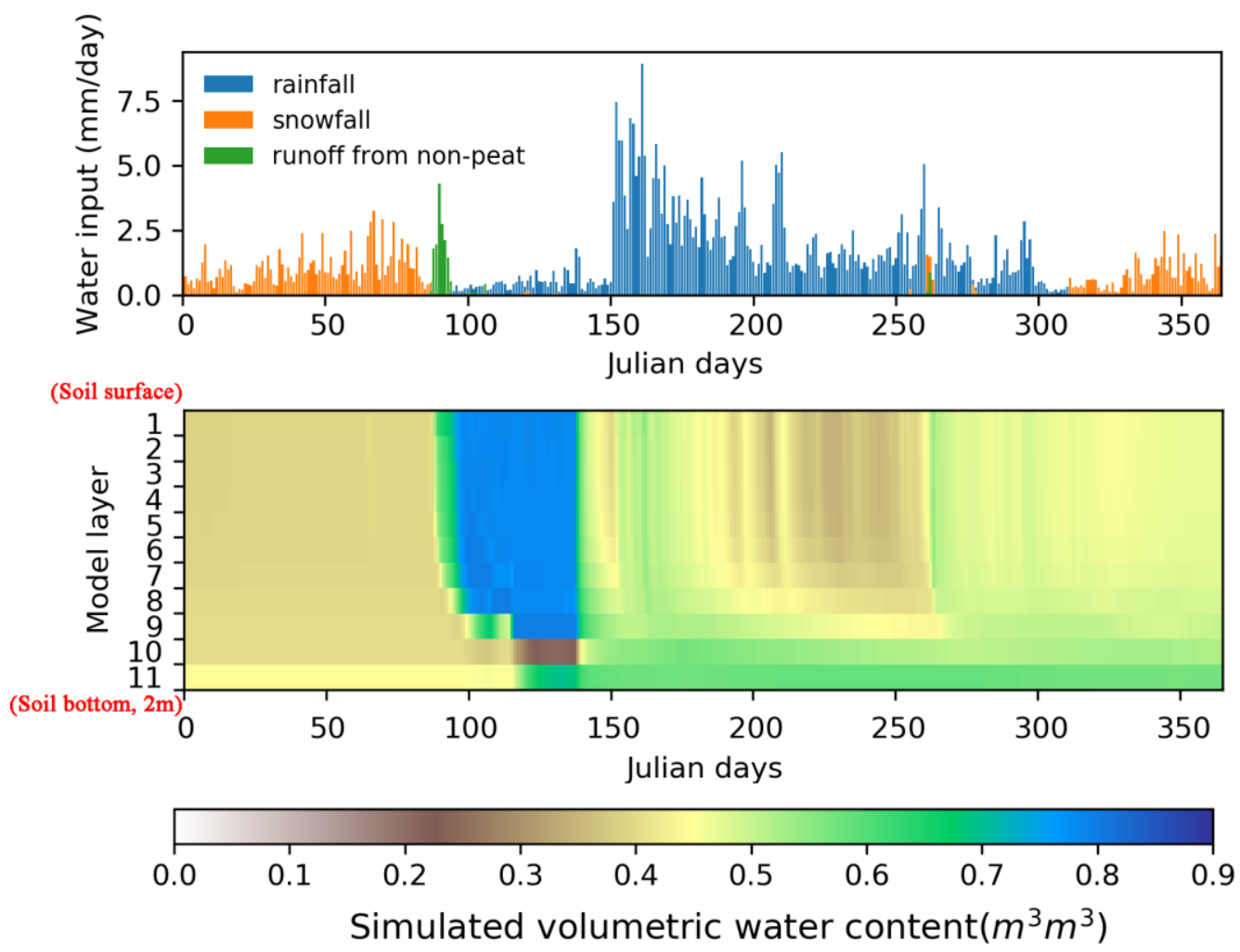

Fig. S14. (Top figure) Daily water inputs to a Sweden peatland $\left(68.0^{\circ} \mathrm{N}, 19.0^{\circ} \mathrm{E}\right)$ in year 1884; (bottom figure) simulated daily volumetric water content profile for the peat HSU. 

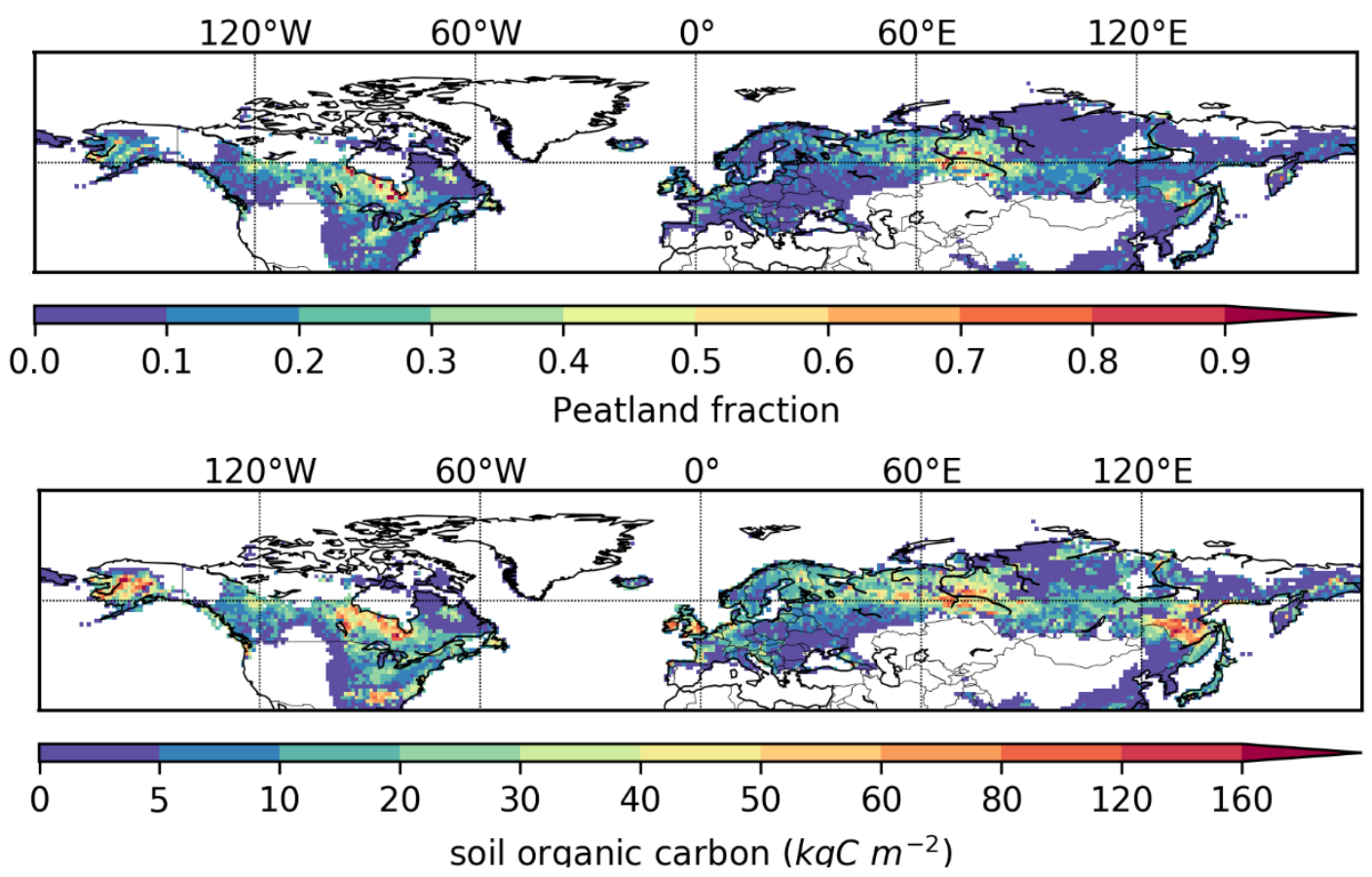

Fig. S15. Same to Fig. S10, but with the prescribed threshold to start C transfer between soil layers $f_{t h}=0.9$. 

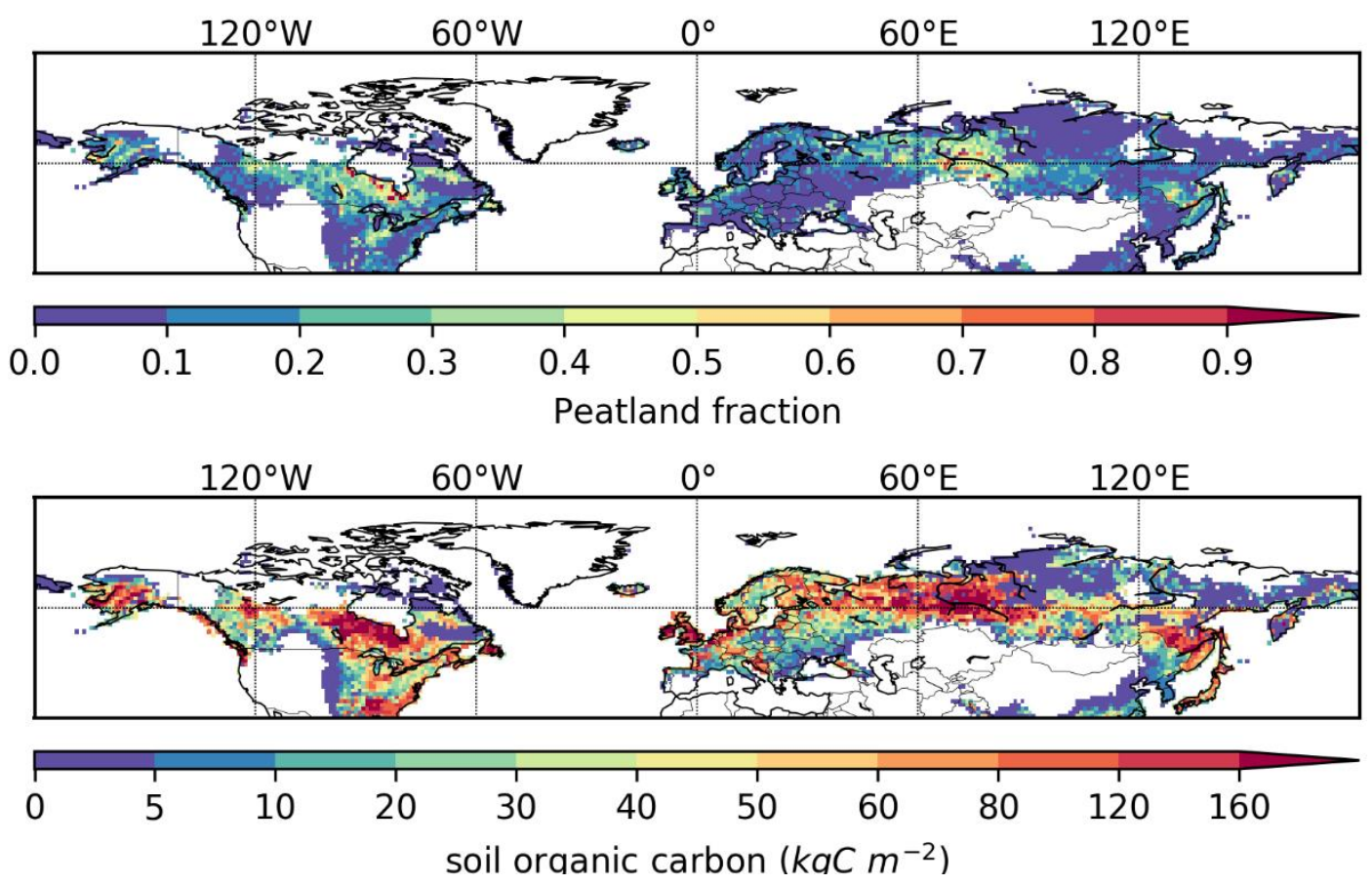

Fig. S16. Same to Fig. S10, but with the e-folding depth of intrinsic decomposition rate $z_{0}=0.5 \mathrm{~m}$. 


\section{References}

Baird, A. J. and Waldron, S.: Shallow horizontal groundwater flow in peatlands is reduced by bacteriogenic gas production, Geophys. Res. Lett., 30(20), 2003.

Batjes, N. H.: ISRIC-WISE Harmonized Global Soil Profile Dataset (ver.3.1), Rep. 2008/02, (December), 2008.

Batjes, N. H.: Harmonized soil profile data for applications at global and continental scales: Updates to the WISE database, Soil Use Manag., 25(2), 124-127, doi:10.1111/j.1475-2743.2009.00202.x, 2009.

Batjes, N. H.: Harmonized soil property values for broad-scale modelling (WISE30sec) with estimates of global soil carbon stocks, Geoderma, 269(February), 61-68, doi:10.1016/j.geoderma.2016.01.034, 2016.

Boutin, C. and Keddy, P. A.: A Functional Classification of Wetland Plants, J. Veg. Sci., 4(5), 591-600, doi:10.2307/3236124, 1993.

Comas, X., Slater, L. and Reeve, A. S.: Atmospheric pressure drives changes in the vertical distribution of biogenic free-phase gas in a northern peatland, J. Geophys. Res. Biogeosciences, 116(4), doi:10.1029/2011JG001701, 2011.

Donald O. Rosenberry, H.Glaser, P. and Siegel, D. I.: The hydrology of northern peatlands as affected by biogenic gas: current developments and research needs, Hydrol. Process., 20, 3601-3610, doi:10.1002/hyp, 2006.

Dyke, A. S.: An outline of North American deglaciation with emphasis on central and northern Canada, Dev. Quat. Sci., 2(PART B), 373-424, doi:10.1016/S15710866(04)80209-4, 2004.

Van Genuchten, M. T.: A closed-form equation for predicting the hydraulic conductivity of unsaturated soils, Soil Sci. Soc. Am. J., 44(5), 892-898, 1980.

Glaser, P. H., Chanton, J. P., Morin, P., Rosenberry, D. O., Siegel, D. I., Ruud, O., Chasar, L. I. and Reeve, A. S.: Surface deformations as indicators of deep ebullition fluxes in a large northern peatland, Global Biogeochem. Cycles, 18(1), doi:10.1029/2003GB002069, 2004.

Gorham, E., Lehman, C., Dyke, A., Janssens, J. and Dyke, L.: Temporal and spatial aspects of peatland initiation following deglaciation in North America, Quat. Sci. Rev., 26(3-4), 300-311, doi:10.1016/j.quascirev.2006.08.008, 2007.

Harden, J. W., Mark, R. K., Sundquist, E. T. and Stallard, R. F.: Dynamics of soil carbon during deglaciation of the laurentide ice sheet., Sci. (New York, NY), 258(5090), 1921 1924, 1992.

Hughes, A. L. C., Gyllencreutz, R., Lohne, Ø. S., Mangerud, J. and Svendsen, J. I.: The last Eurasian ice sheets - a chronological database and time-slice reconstruction, DATED-1, Boreas, 45(1), 1-45, doi:10.1111/bor.12142, 2016.

Joosten, H.: The Global Peatland $\mathrm{CO} 2$ picture. Peatland status and drainage related emissions in all countries of the world, Wetl. Int. Ede, 2010 [online] Available from: http://scholar.google.com/scholar?hl=en\&btnG=Search\&q=intitle:The+Global+Peatla $\mathrm{nd}+\mathrm{CO}+2+$ Picture + Peatland + status + and + drainage + related + emissions + in + all + countri es+of+the+world\#0, 2010.

Kellner, E., Waddington, J. M. and Price, J. S.: Dynamics of biogenic gas bubbles in peat: Potential effects on water storage and peat deformation, Water Resour. Res., 41(8), 
1-12, doi:10.1029/2004WR003732, 2005.

Krinner, G., Viovy, N., de Noblet-Ducoudré, N., Ogée, J., Polcher, J., Friedlingstein, P., Ciais, P., Sitch, S. and Prentice, I. C.: A dynamic global vegetation model for studies of the coupled atmosphere-biosphere system, Global Biogeochem. Cycles, 19(1), 1-33, doi:10.1029/2003GB002199, 2005.

Largeron, C., Krinner, G., Ciais, P. and Brutel-Vuilmet, C.: Implementing northern peatlands in a global land surface model: description and evaluation in the ORCHIDEE high-latitude version model (ORC-HL-PEAT), Geosci. Model Dev., 11(8), 3279-3297, 2018.

Loisel, J., Yu, Z., Beilman, D. W., Camill, P., Alm, J., Amesbury, M. J., Anderson, D., Andersson, S., Bochicchio, C., Barber, K., Belyea, L. R., Bunbury, J., Chambers, F. M., Charman, D. J., De Vleeschouwer, F., Fia kiewicz-Kozie , B., Finkelstein, S. a., Ga ka, M., Garneau, M., Hammarlund, D., Hinchcliffe, W., Holmquist, J., Hughes, P., Jones, M. C., Klein, E. S., Kokfelt, U., Korhola, a., Kuhry, P., Lamarre, a., Lamentowicz, M., Large, D., Lavoie, M., MacDonald, G., Magnan, G., Makila, M., Mallon, G., Mathijssen, P., Mauquoy, D., McCarroll, J., Moore, T. R., Nichols, J., O’Reilly, B., Oksanen, P., Packalen, M., Peteet, D., Richard, P. J., Robinson, S., Ronkainen, T., Rundgren, M., Sannel, a. B. K., Tarnocai, C., Thom, T., Tuittila, E.-S., Turetsky, M., Valiranta, M., van der Linden, M., van Geel, B., van Bellen, S., Vitt, D., Zhao, Y. and Zhou, W.: A database and synthesis of northern peatland soil properties and Holocene carbon and nitrogen accumulation, The Holocene, 24(9), 1028-1042, doi:10.1177/0959683614538073, 2014.

MacDonald, G. M., Beilman, D. W., Kremenetski, K. V., Sheng, Y., Smith, L. C. and Velichko, A. A.: Rapid Early Development of Circumarctic Peatlands and Atmospheric CH4 and CO2 Variations, Science (80-. )., 314(5797), 285-288, doi:10.1126/science.1131722, 2006.

Moyano, F. E., Vasilyeva, N., Bouckaert, L., Cook, F., Craine, J., Curiel Yuste, J., Don, A., Epron, D., Formanek, P., Franzluebbers, A., Ilstedt, U., Kätterer, T., Orchard, V., Reichstein, M., Rey, A., Ruamps, L., Subke, J. A., Thomsen, I. K. and Chenu, C.: The moisture response of soil heterotrophic respiration: Interaction with soil properties, Biogeosciences, 9(3), 1173-1182, doi:10.5194/bg-9-1173-2012, 2012.

Mualem, Y.: A new model for predicting the hydraulic conductivity of unsaturated porous media, Water Resour. Res., 12(3), 513-522, 1976.

Parton, W. J., Stewart, J. W. B. and Cole, C. V: Dynamics of C , N , P and S in grassland soils : a model, Biogeochemistry, 131(5), 109-131, 1988.

Payette, S.: Peat inception and climatic change in northern Quebec, in Climatic Changes on a Yearly to Millennial Basis, pp. 173-179, Springer., 1984.

Qiu, C., Zhu, D., Ciais, P., Guenet, B., Krinner, G., Peng, S., Aurela, M., Bernhofer, C., Brümmer, C., Bret-Harte, S., Chu, H., Chen, J., Desai, A. R., Dušek, J., Euskirchen, E. S., Fortuniak, K., Flanagan, L. B., Friborg, T., Grygoruk, M., Gogo, S., Grünwald, T., Hansen, B. U., Holl, D., Humphreys, E., Hurkuck, M., Kiely, G., Klatt, J., Kutzbach, L., Largeron, C., Laggoun-Défarge, F., Lund, M., Lafleur, P. M., Li, X., Mammarella, I., Merbold, L., Nilsson, M. B., Olejnik, J., Ottosson-Löfvenius, M., Oechel, W., Parmentier, F.-J. W., Peichl, M., Pirk, N., Peltola, O., Pawlak, W., Rasse, D., Rinne, J., 
Shaver, G., Schmid, H. P., Sottocornola, M., Steinbrecher, R., Sachs, T., Urbaniak, M., Zona, D. and Ziemblinska, K.: ORCHIDEE-PEAT (revision 4596), a model for northern peatland $\mathrm{CO} 2$, water, and energy fluxes on daily to annual scales, Geosci. Model Dev., 11(2), 497-519, doi:10.5194/gmd-11-497-2018, 2018.

Romanowicz, E. A., Chanton, J. P. and Glaser, P. H.: Temporal variations in dissolved methane deep in the Lake Agassiz Peatlands, Minnesota, Global Biogeochem. Cycles, 9(2), 197-212, 1995.

De Rosnay, P., Bruen, M. and Polcher, J.: Sensitivity of surface fluxes to the number of layers in the soil model used in GCMs, Geophys. Res. Lett., 27(20), 3329-3332, 2000. De Rosnay, P., Polcher, J., Bruen, M. and Laval, K.: Impact of a physically based soil water flow and soil-plant interaction representation for modeling large-scale land surface processes, J. Geophys. Res. Atmos., 107(D11), 2002.

Stocker, B. D., Spahni, R. and Joos, F.: DYPTOP: A cost-efficient TOPMODEL implementation to simulate sub-grid spatio-temporal dynamics of global wetlands and peatlands, Geosci. Model Dev., 7(6), 3089-3110, doi:10.5194/gmd-7-3089-2014, 2014. Strack, M., Kellner, E. and Waddington, J. M.: Dynamics of biogenic gas bubbles in peat and their effects on peatland biogeochemistry, Global Biogeochem. Cycles, 19(1), 1-9, doi:10.1029/2004GB002330, 2005.

Strack, M., Kellner, E. and Waddington, J. M.: Effect of entrapped gas on peatland surface level fluctuations, Hydrol. Process., 20(17), 3611-3622, doi:10.1002/hyp, 2006. Tootchi, A., Jost, A. and Ducharne, A.: Multi-source global wetland maps combining surface water imagery and groundwater constraints, Earth Syst. Sci. Data, 11(1), 189220, doi:10.5194/essd-11-189-2019, 2019.

Zhu, D., Peng, S., Ciais, P., Zech, R., Krinner, G., Zimov, S. and Grosse, G.: Simulating soil organic carbon in yedoma deposits during the Last Glacial Maximum in a land surface model, Geophys. Res. Lett., 43(10), 5133-5142, doi:10.1002/2016GL068874, 2016. 